\title{
PENGARUH SELF-COMPASSION TERHADAP KESEPIAN PADA MAHASISWA RANTAU
}

\author{
Diani Pratiwi, Tina Hayati Dahlan, Lira Fessia Damaianti \\ Departemen Psikologi, Universitas Pendidikan Indonesia. \\ Email: dianipra@student.upi.edu
}

\begin{abstract}
:
This study aimed to determine the effect of self-compassion on loneliness, of overseas student in University of Education Indonesia. The study used quantitative method with 260 participants. The research used instruments Indonesian Self-compassion Scale - Short Version (Oktyana, 2013) and UCLA Loneliness Scale Version 3 to measure loneliness adapted by Irsalina (2013) from Rusell (1996). This used simple regression to analyze the effect of Self Compassion to Lonelines. The result showed there were significant effect of self-compassion to loneliness with $R$ square 0,096. The freshmen tend to lonelines, so the university must overcome their loneliness.
\end{abstract}

Keyword : Self-compassion, lonliness, oversaes student.

\begin{abstract}
Abstrak:
Penelitian ini bertujuan untuk mengetahui pengaruh self-compassion terhadap kesepian pada mahasiswa rantau luar Jawa Barat angkatan 2018 di Universitas Pendidikan Indonesia. Teknik pengambilan responden menggunakan nonprobability sampling, yaitu purposive sampling, yang berjumlah 260 mahasiswa. Instrumen penelitian ini menggunakan terjemahan Self-compassion Scale - Short Version (Oktyana, 2013) serta terjemahan UCLA Loneliness Scale Version 3 (Irsalina, 2013). Teknik analisis data yang digunakan dalam penelitian ini adalah regresi sederhana. Hasil penelitian ini menunjukan bahwa terdapat pengaruh signifikan self-compassion terhadap kesepian dengan kontribusi self-compassion sebesar $9.6 \%$ terhadap kesepian. Rekomendasi untuk studi selanjutnya dapat melihat faktor-faktor lain yang berkaitan dengan self-compassion ataupun kesepian.
\end{abstract}

Kata kunci: self-compassion, kesepian, mahasiswa rantau. 


\section{PENDAHULUAN}

Kesepian di dalam kehidupan sosial dapat dialami oleh siapa saja baik pada orang yang bekerja maupun pelajar. Menurut Cherly \& Parello (2008) apabila kesepian sudah menjadi sebuah kesedihan maka, individu yang merasa kesepian cenderung kurang peduli terhadap kesehatan tubuhnya sehingga menimbulkan depresi, pola makan yang tidak sehat, dan menurunnya sistem kekebalan tubuh. Hal tersebut juga diperkuat oleh Masi (dkk, 2011) bahwa kesepian merupakan suatu keadaan yang tidak baik, perasaan kekosongan dan kurangnya hubungan sosial yang berdampak pada kesehatan fisik serta tekanan mental dalam diri.

Kesepian dapat dialami oleh siapa saja termasuk mahasiswa rantau. Salah satu fakor yang memengaruhi kesepian adalah adanya perpindahan lingkungan baru pada mahasiswa khususnya mahasiswa baru (Baron \& Byrne, 2005). Menurut Halim \& Dariyo (2016) perpindahan yang dilakukan oleh mahasiswa rantau salah satunya adalah untuk mendapatkan pendidikan yang layak. Merantau merupakan fenomena yang sudah tidak asing lagi terutama bagi mahasiswa. Badan Pusat Statistik tahun 2017 menunjukan bahwa pada periode 2015/2016, sekitar 1.254.966 mahasiswa menempuh pendidikan di Bandung, hal ini menjadikan Bandung sebagai salah satu kota dengan mahasiswa terbanyak. Tribun Jabar tahun 2018 memberitakan bahwa Universitas Pendidikan Indonesia (UPI) berada pada urutan pertama yang menerima mahasiswa terbanyak melalui SNMPTN dan menjadi urutan ke tujuh yang menerima mahasiswa terbanyak melalui SBMPTN. Menurut data yang diterima dari Sistem Informasi UPI, mahasiswa rantau luar Jawa Barat tahun ajaran 2018/2019 terdapat sebanyak 732 mahasiswa. Tidak meratanya kualitas perguruan tinggi di Indonesia menyebabkan banyaknya mahasiswa yang pindah dari kota asalnya untuk menimba ilmu lebih baik di wilayah Pulau Jawa khususnya Bandung.

Peneliti melakukan wawancara kepada dua mahasiswa rantau angkatan 2016 berjenis kelamin perempuan yang sedang menimba ilmu di Universitas Pendidikan Indonesia (UPI). Dari wawancara tersebut peneliti mendapatkan informasi bahwa mereka mengalami kesepian. Mereka mengalami kesepian pada saat memasuki masa awal perkuliahan. Meskipun tidak terlalu sering, jauh dari orang tua dan berpisah dengan lingkungan lamanya memiliki dampak kesepian bagi mereka yaitu merasa gelisah dan selalu berakhir dengan menangis. Menurut mereka penyebab munculnya kesepian adalah karena merasa rindu dengan orang tua, terkadang mereka merasa bahwa teman-teman di lingkungan baru kurang memahaminya sehingga kesepian yang dialaminya memiliki dampak yaitu menjadi susah tidur, sedih, dan terkadang menangis. 
Terdapat perbedaan yang ditemui individu ketika melakukan perpindahan dari satu daerah ke daerah lain seperti, kultur budaya, bahasa, kondisi tempat tinggal serta perubahan lingkungan (Marta, 2014). Hal tersebut menjadi tantangan tersendiri bagi mahasiswa asal luar Jawa Barat yang sedang menempuh pendidikan di Jawa Barat. Budaya Jawa Barat memiliki nilai-nilai yang sudah ada sejak lama seperti nilai kesopanan, rendah hati terhadap sesama, hormat kepada yang lebih tua, dan menyayangi kepada yang lebih kecil (Abdulkarim, dkk, 2010). Budaya dan lingkungan baru dapat membuat mahasiswa rantau untuk hidup lebih mandiri dan berusaha untuk memahami budaya baru.

Tuntutan untuk memahami budaya di lingkungan baru dan berusaha mandiri dapat membuat individu kesepian. Hal ini mungkin dapat berlaku pada mahasiswa rantau semester awal. Hal ini sejalan dengan penelitian yang dilakukan oleh Perlman (dalam Halim \& Dariyo, 2016) bahwa remaja dan orang dewasa awal lebih sering mengalami kesepian dibandingkan dengan individu yang lebih tua. Mental Health Foundation tahun 2010 menemukan bahwa kesepian lebih sering terjadi pada usia 1834 tahun dibandingkan dengan kelompok usia diatas 55 tahun.

Penelitian oleh Heinrich \& Gullone (dalam Goossens, dkk, 2014) menyatakan bahwa tingkat kesepian yang paling tinggi dimiliki oleh remaja akhir yang baru memasuki universitas. Hal ini dikarenakan remaja akhir banyak mengalami transisi sosial seperti meninggalkan rumah seorang diri, memasuki masa kuliah, atau memasuki dunia kerja. Menurut Steinberg (2002) usia remaja akhir yaitu berkisar antara umur 18-21 tahun. Taylor dkk (dalam Halim \& Dariyo, 2016) menemukan bahwa semakin individu bertambah usia maka kehidupan dan kemampuan sosial lebih stabil dan baik, serta dalam hubungan sosial individu tersebut lebih realistis.

Menurut Tuncay \& Ozdemir (2008) mahasiswa rantau rentan mengalami kesepian dikarenakan latar belakang budaya yang berbeda antara tempat tinggal asal dengan tempat perantauan. Penelitian tersebut juga menemukan bahwa jauh dari orang tua mengharuskan mereka untuk memilki sifat mandiri sehingga menjadikan mereka lebih tertekan dan putus asa (Tuncay \& Ozdemir, 2008). Selain putus asa, depresi juga menjadi salah satu akibat dari perasaan kesepian pada mahasiswa (Daniel, 2013).

Kesepian yang dirasakan oleh individu khususnya mahasiswa rantau dapat diatasi oleh self-compassion. Menurut Neff (2003) self-compassioni didefinisikan sebagai bentuk kasih sayang pada diri sendiri, tidak menghindari permasalahan, melainkan melihat bahwa situasi negatif yang dialami merupakan bagian dari pengalaman hidup manusia. Seseorang yang memiliki self-compassion dapat membatasi emosi negatif dengan kesadaran penuh disertai empati (Neff, 2003). Hal ini secara tidak langsung 
menyatakan bahwa self-compassion dapat membuat emosi negatif menjadi emosi positif (Neff \& Vonk, 2009). Hasil penelitian yang dilakukan oleh Neff \& Vonk (2009) pada 102 mahasiswa yang dipilih secara acak menunjukan bahwa mahasiswa yang memiliki self-compassion tinggi lebih sedikit menunjukkan emosi negatif dibandingkan dengan mahasiswa dengan tingkat self-compassion rendah. Hasil tersebut memperlihatkan bahwa keberadaan self-compassion efektif dalam mengendalikan emosi-emosi negatif yang muncul dalam diri individu.

Pada penelitian sebelumnya tentang self-compassion dan kesepian dilakukan pada variabel yang berbeda, misalnya kesepian dengan psychological well-being. Hasil penelitian oleh Halim \& Dariyo (2011) menyatakan bahwa psychological well-being memiliki hubungan negatif dengan kesepian. Terdapat juga penelitian sebelumnya mengenai self-compassion dengan resiliensi. Hasil Febrinabillah \& Listyandini (2016) menunjukan bahwa terdapat hubungan yang signifikan dan bernilai positif antara self-compassion dengan resiliensi.

Terdapat penelitian mengenai self-compassion dan kesepian yang dilakukan oleh Hidayati (2015), penelitian tersebut tidak dilakukan pada mahasiswa rantau semester pertama akan tetapi dilakukan terhadap siswa pesantren SMP. Hasil penelitian oleh Hidayati (2015) menunjukan bahwa tidak terdapat hubungan antara self-compassion dan kesepian. Pada penelitiannya Hidayati (2015) menemukan bahwa siswa pesantren SMP memiliki kegiatan yang padat sehingga perasaan kesepian lebih jarang muncul.

Penelitian mengenai self-compassion dan kesepian juga pernah diteliti oleh Akin (2010), akan tetapi penelitian tersebut tidak dilakukan di Indonesia melainkan di negara Turki. Perbedaan budaya dapat terjadi oleh Negara manapun termasuk Negara Indonesia dan Negara Turki. Dalam segi budaya, Negara Turki merupakan satusatunya negara yang memadukan budaya Barat dan budaya Timur, dengan memadukan budaya Barat dan budaya Timur, orang-orang di Negara Turki memiliki sifat lebih selektif dalam banyak hal, sikap disiplin yang tinggi, to the point dalam berbicara (Maharani, 2015). Sedangkan Indonesia merupakan negara yang terletak di benua Asia dan merupakan Negara kepulauan dengan multi etnis, sehingga terdapat berbagai macam budaya yang berbeda disetiap daerah. Selain itu orang-orang Asia memiliki kebudayaan kolektif seperti bergotong royong, memiliki sifat ramah tamah, dan menghargai orang lain dibandingkan dengan budaya Barat atau Timur, sifat tersebut menjadikan orang-orang Asia cenderung memiliki self-compassion yang tinggi (Kitayama \& Markus, 2000). Penelitian mengenai self-compassion dan kesepian pada mahasiswa rantau belum banyak ditemukan oleh peneliti. 
Berdasarkan fenomena yang sudah dijelaskan, peneliti merasa penting untuk melakukan penelitian mengenai pengaruh self-compassion terhadap kesepian pada mahasiswa rantau.

\section{METODE}

Penelitian ini menggunakan pendekatan kuantitatif, metode yang digunakan yaitu analisis regresi. Responden dalam penelitian ini adalah mahasiswa rantau semester awal yang berasal dari luar Jawa Barat dengan jenjang pendidikan S1 di Universitas Pendidikan Indonesia (UPI) sebanyak 260 orang.

Pada penelitian ini variabel self-compassion diukur dengan menggunakan instrumen Self-compassion Scale - Short Version yang diadaptasi oleh Oktiana (2017) dari Neff (2011) yang terdiri atas 12 item yang memiliki reliabilitas 0,63. Variabel kesepian diukur dengan menggunakan instrumen UCLA Loneliness Scale Version 3 yang diadaptasi oleh Irsalina (2017) dari Rusell (1996) yang terdiri dari 20 item yang memiliki reliabilitas 0,89 .

\section{HASIL}

Skor rata-rata self-compassion sebesar 52.6595 dengan skor maximum 76.65 dan skor minimum 38.61 dengan standar deviasi 5639. Self-compassion dapat membuat perasaan negatif, kegagalan dan penderitaan menjadi hal yang wajar dialami oleh semua manusia dan dapat berlapang dada. Memiliki sikap belas kasih (selfcompassion) terhadap diri sendiri bisa menjadi awal dalam mengatasi segala emosiemosi negatif yang dirasakan, seperti kesepian. Self-compassion meliputi aspekaspek, yaitu self-kindness versus self-judgement, common humanity versus isolation dan mindfulness versus overidentification (Germer \& Neff , 2013). Dengan self kindness, individu pada saat terjadi permasalahan tidak menghakimi diri sendiri serta menghindari perasaan rendah diri, sebaliknya dengan self-judgement individu akan menghadapi permasalahan dengan mengkritik diri sendiri, menghakimi bahwa permasalahan tersebut merupakaan kesalahan diri sendiri (Germer \& Neff, 2013). Pada konteks mahasiswa rantau yang berpisah dengan orang tua serta harus

meninggalkan lingkungan lamanya, apabila ia memiliki perasaan untuk tidak 
menghakimi dan menyalahkan diri sendiri mengenai permasalahan yang terjadi maka ia akan dapat menerima permasalahan tersebut dengan lapang dada tanpa adanya perasaan rendah diri. Apabila individu tidak memiliki perasaan untuk menerima diri sendiri, selalu mencoba untuk menghakimi diri sendiri maka individu tersebut akan sulit menerima permasalahan yang ada dengan lapang dada.

Tabel 1

Statistik Deskriptif

\begin{tabular}{lllll}
\hline Variabel & Rata-rata & Maksimum & Minimum & SD \\
\hline Self-Compassion & 52.6595 & 76.65 & 38.61 & 5.639 \\
Kesepian & 45.3617 & 85.38 & 14.47 & 10.548 \\
\hline
\end{tabular}

Secara deskriptif, rata-rata kesepian sebesar 45.3617 dengan skor maksimum 85.38 dan skor minimum 14.47 dengan Standar Deviasi 10,548. Kesepian muncul karena adanya perasaan terasing, kurangnya hubungan yang bermakna dengan orang lain, kekosongan, kebosanan, tidak bahagia, serta kurang puas dengan hubungan sosialnya (Baron \& Bryne, 2005, Bruno dalam Sears, 2005, Myers, 2010, Sonderby \& Wagoner, 2013).

Tabel 2

Regresi Linier Self-Compassion terhadap Kesepian

\begin{tabular}{llllll}
\hline & $\mathbf{B}$ & $\mathbf{T}$ & Sig. & $\mathbf{R}$ & $\mathbf{R}^{\mathbf{2}}$ \\
\hline Konstanta & 75.890 & 12.943 & .000 & \multirow{2}{*}{-310} & .096 \\
\cline { 1 - 5 } Self-compassion & -.580 & -.5 .236 & .000 & & \\
\hline
\end{tabular}

Hasil penelitian menunjukan koefisien korelasi sebesar -0.310 dengan taraf signifikansi sebesar $0.000 \quad(\rho<0.05)$. Hasil negatif menunjukan bahwa pengaruh kedua variabel penelitian bernilai negatif. Hasil perhitungan dari penelitian ini menunjukan bahwa self-compassion berkontribusi sebesar 9,6\% terhadap kesepian dan diharapkan dapat mampu menurunkan kesepian pada mahasiswa rantau di Universitas Pendidikan Indonesia. Selain itu sebesar 90.4\% disebabkan karena adanya faktor-faktor lain yang tidak dijelaskan dalam penelitian ini. Hal ini sesuai 
dengan pernyataan Allen \& Leary (2010) bahwa individu yang memiliki selfcompassion yang tinggi tidak melihat bahwa situasi negatif sebagai suatu bencana, dan tidak menghindari tugas yang menantang dikarenakan takut akan kegagalan. Sedangkan individu yang memiliki tingkat self-compassion yang rendah cenderung melihat situasi negatif sebagai suatu bencana, dan takut pada situasi yang menekan serta adanya kegagalan.

Responden dalam penelitian ini merupakan remaja akhir dimana remaja akhir merupakan masa transisi sosial seperti meninggalkan rumah seorang diri, memasuki masa kuliah, tuntutan untuk hidup mandiri dan memahami budaya baru (Heinrich \& Gullone dalam Goossens, dkk, 2014). Self-compassion dapat menjadi cara untuk menurunakan permasalahan-permasalahan yang muncul pada masa transisi remaja akhir. Hal ini juga diungkapkan oleh Narang (2014) yang menjeleskan bahwa individu yang mampu berbuat baik terhadap diri sendiri dan tidak membuat diri terus menerus memikirkan pikiran yang negatif akan dapat memandang dirinya secara positif, sehingga tidak akan merasa sendiri dalam hidupnya. Artinya dengan selfcompassion permasalahan yang dialami oleh remaja akhir dapat diatasi dengan baik, karena remaja akhir yang memiliki self-compassion dapat memandang diri dan permasalahan secara positif.

\section{PEMBAHASAN}

Mahasiswa rantau di tahun pertama kuliah dapat mengalami banyak tantangan. Tuntutan akademik yang lebih tinggi serta tuntutan untuk menjadi mandiri akan menjadi stressor bagi mahasiswa (Marta, 2014). Perpindahan yang dilakukan oleh mahasiswa rantau yang sedang menempuh perguruan tinggi dapat menghadapi situasi-situasi seperti tinggal terpisah dari keluarga, sulit beradaptasi, adanya latar belakang sosial budaya yang berbeda, masalah dengan lawan jenis (Halim \& Dariyo, 2016). Adanya culture shock dan jarak yang jauh dengan rumah membuat mahasiswa rantau harus berusaha lebih keras dalam beradaptasi dengan lingkungan sosial yang baru baik dalam segi bahasa maupun aturan-aturan yang ada didalam lingkungan barunya (Wijanarko \& Syafiq, 2013). Perpisahan dengan keluarga juga dapat menjadikan mahasiswa rantau untuk hidup lebih mandiri.

Individu yang dapat mencintai dirinya, menghargai diri sendiri, dapat berdamai dengan diri sendiri terkait permasalahan yang dialami akan lebih mudah menerima 
perbedaan budaya, perpisahan dengan orang tua dan teman-teman lamanya sehingga permasalahan tersebut tidak mengahalanginya dalam proses pengembangan diri dimana didalamnya terdapat tuntutan untuk mampu menyelesaikan permasalahan yang terjadi dengan emosi positif seperti perasaan kesepian.

Sikap mencintai dan menghargai diri sendiri juga disebut dengan self-compassion. Self-compassion dapat membuat perasaan negatif, kegagalan dan penderitaan menjadi hal yang wajar dialami oleh semua manusia dan dapat berlapang dada. Memiliki sikap belas kasih (self-compassion) terhadap diri sendiri bisa menjadi awal dalam mengatasi segala emosi-emosi negatif yang dirasakan, seperti kesepian.

Self-compassion meliputi aspek-aspek, yaitu self-kindness versus self-judgement, common humanity versus isolation dan mindfulness versus overidentification (Germer \& Neff , 2013). Dengan self kindness, individu pada saat terjadi permasalahan tidak menghakimi diri sendiri serta menghindari perasaan rendah diri, sebaliknya dengan self-judgement individu akan menghadapi permasalahan dengan mengkritik diri sendiri, menghakimi bahwa permasalahan tersebut merupakaan kesalahan diri sendiri (Germer \& Neff, 2013). Pada konteks mahasiswa rantau yang berpisah dengan orang tua serta harus meninggalkan lingkungan lamanya, apabila ia memiliki perasaan untuk tidak menghakimi dan menyalahkan diri sendiri mengenai permasalahan yang terjadi maka ia akan dapat menerima permasalahan tersebut dengan lapang dada tanpa adanya perasaan rendah diri. Apabila individu tidak memiliki perasaan untuk menerima diri sendiri, selalu mencoba untuk menghakimi diri sendiri maka individu tersebut akan sulit menerima permasalahan yang ada dengan lapang dada.

Selanjutnya dengan common humanity, individu dapat memiliki kesadaran bahwa suatu permasalahan atau kesulitan merupakan bagian dari kehidupan yang mana bukan hanya terjadi pada diri sendiri tetapi hal tersebut merupakan sesuatu yang dapat dialami oleh semua orang, sebaliknya dengan isolation individu akan merasa bahwa kesulitan atau permasalahan hanya dialami oleh diri sendiri sehingga individu tersebut menyalahkan diri sendiri akan situasi yang dialami (Germer \& Neff, 2013). Misalnya pada mahasiswa rantau yang dihadapkan oleh suatu permasalahan, apabila ia dapat menerima permasalahan tersebut maka ia tidak akan membandingkan keadaan diri sendiri dengan orang lain serta ia akan memiliki perasaan bahwa permasalahan tersebut merupakan bagian dalam kehidupan dan bukan hanya terjadi pada dirinya akan tetapi juga dapat terjadi pada setap individu. Apabila individu selalu merasa bahwa permasalahan atau keadaan saat ini hanya ia yang dapat mengalaminya, maka individu tersebut dapat membuat perasaan menghakimi dan tidak menerima. 
Kemudian dengan mindfulness individu dapat melihat permasalahan atau keadaan secara jelas, lebih terbuka serta dapat merencanakan sikap apa yang akan ditunjukan pada permasalahan atau keadaan tertentu, sebaliknya dengan over-identification individu tersebut lebih menutup diri dengan masalah yang dihadapi, serta berpikir secara negatif mengenai penyelesaian akan suatu permasalahan (Germer \& Neff, 2013). Misalnya pada mahasiswa rantau yang harus berpisah dengan keluarga serta menetap di lingkungan dan budaya baru yang mengharuskan untuk hidup mandiri, apabila ia lebih terbuka dalam menghadapi masalah maka ia akan lebih tahu serta akan lebih berupaya dalam bagaimana cara menghadapi terhadap hal-hal tertentu dengan porsi yang tepat, berpikir secara objektif, serta dapat memikirkan sikap yang positif untuk menghadapi permasalahan terebut. Sedangkan mahasiswa rantau yang tertutup mengenai permasalahan yang terjadi maka ia akan memiliki sikap yang negatif dalam menghadapi permasalahan.

\section{KESIMPULAN}

Berdasarkan hasil dan pembahasan yang telah dipaparkan sebelumnya mengenai pengaruh self-compassion terhadap kesepian pada mahasiswa rantau di Universitas Pendidikan Indonesia tahun angkatan 2018 yang berasal dari luar Jawa Barat dapat disimpulkan bahwa dengan self-compassion yang berkontribusi sebesar 9,6\% dapat diharapkan mampu menurunkan kesepian pada mahasiswa rantau di Universitas Pendidikan Indonesia. Pengaruh self-compassion terhadap kesepian tersebut bersifat negatif.

\section{DAFTAR PUSTAKA}

Abdulkarim, A., \& Iqbal, M., Majid, M. A. S. R. V. (2010). Peran Nilai Budaya Sunda Dalam Pola Asuh Orang Tua Bagi Pembentukan Karakter Sosial Anak. Jurnal Empati, 9(1), 1-7.

Allen, A. B. \& Leary, M. R. (2010). Self-compassion, stress, and coping. Soc Personal Psychol Compass, 4(2), 107-118

Badan Pusat Statistik. (2017). Jumlah perguruan tinggi, mahasiswa, dan tenaga edukatif (negeri dan swasta) di bawah kementrian pendidikan dan kebudayaan 
menurut provinsi 2015/2016. BPS. Diunduh dari http://www.bps.go.id/link TabelStatis/vi ew/id/1839.

Baron, R. A., \& Byrne, D. (2005). Psikologi sosial. Edisi kesepuluh. Jakarta: Erlangga.

Cheryl, A.,\& Parello, K. (2008). Loneliness in the School Setting. The Journal of School Nursing, 24(2). 66-70.

Daniel, K. (2013). Loneliness and Depression among University Students in Kenya. GlobalJurnal of Human Social Science Arts \& Humanities. 13(4), 1-9.

Goossens, L., Klimstra, T., Luyckx, K., Vanhalst, J., \& Teppers, E. (2014). Reliability and validity of the roberts UCLA loneliness scale (RULS-8) with dutch-speaking adolescents in Belgium. Psychologica Belgica, 54(1), 5-18.

Halim, C. F., \& Dariyo, A. (2016). Hubungan Psychological Well-Being dengan Loneliness Pada Mahasiswa yang Merantau. Jurnal Psikogenesis, 4(2), 1-12.

Marta, S. (2014). Kontruksi Makna Budaya Merantau di Kalangan Mahasiswa Perantau. Jurnal Kajian Komunikasi, 2(1), 1-17.

Masi, C. M., His, Y. C., Louise, C.H, dan John T.C. (2011). A Meta-Analysis of Interventions to Reduce Loneliness, Personality and Social Psychology Review. $15(3), 219-266$.

Narang, D. S. (2014). Leaving loneliness: A workbook, building relationships with yourself and others. Los Angeles: Stronger Relationships LLC.

Neff, K. D. (2003). The Development and Validation of a Scale to Measure SelfCompassion. Self and Identitiy Journal. 2(3), 223-250.

Neff, K. D., \& Vonk, Roos. (2009). Self-Compassion Versus Global Self-Esteem: Two Different Ways of Relating to Oneself. Journal of Personality, 77(1), 864867.

Steinberg, Lawrence. 2002. Adolescence. Sixth edition, New York: McGraw Hill Inc.

Tuncay, T., \& Ozdemir, U. (2008). Corelates of Loneliness Among Unversity Students. Child Adolesce Psychiatry Ment Health, 29(2), 1-6. 